\title{
SELENIUM IN BIOLOGICAL FLUIDS IN THE BODIES OF PATIENTS WITH ASSOCIATED TRAUMA
}

Vasiuk V. Le., PhD in Traumatology, Professor, Department of Traumatology and Orthopedics Kovalchuk P. Ye., PhD in Traumatology, Assoc. Professor, Department of Traumatology and Orthopedics Tulyulyuk S. V., Assistant, Department of Traumatology and Orthopedics

Shutka V. J., MD, PhD, Assoc. Professor, Department of Urology and Neurosurgery

Higher State Educational Establishment of Ukraine

"Bukovinian State Medical University», Ukraine.

DOI: https://doi.org/10.31435/rsglobal_ws/31082019/6631

\section{ARTICLE INFO}

Received: 15 June 2019

Accepted: 23 August 2019

Published: 31 August 2019

\section{KEYWORDS}

selenium,

associated trauma,

biological fluids.

\begin{abstract}
Modern literature widely covers the role of selenium and necessity of its intake in case of different diseases, but the studies concerning the dynamics of concentration of this element in patients with injuries of the muscularskeletal system (MSS) and cranial-cerebral injuries (CCI) are isolated. At the same time, investigation of selenium metabolism in case of injuries of the MSS and CCI and development of the correction schemes are generally known to enable to improve the results of treatment considerably and decrease the consequences of injuries.

Objective: to investigate the concentration of selenium in biological fluids in patients with associate trauma.

Materials and methods: 42 patients, treated at the Traumatological Department for adults and Neurosurgical Department of the Emergency Rescue Hospital in Chernivtsi, were examined. All the patients were distributed into 3 groups: I group - patients with severe CCI and injuries of the MSS requiring vital activity support; II group - with moderate CCI and injuries of the MSS; III (control group) - with injuries of MSS only.

Results: The data obtained are indicative of decreased selenium concentration in all the biological media of the body (plasma, erythrocytes, urine) during the whole post-traumatic period, both in patients with severe $\mathrm{CCI}$ and injuries of the MSS and those with a moderate degree.

Conclusions: 1. Pronounced disorders of selenium metabolism are evidenced to occur in patients with severe CCI and MSS injuries, which are manifested by its decreased concentration in all the examined biological media of the body during the whole acute period of injury. 2. The lack of considerable differences in selenium concentration in patients with severe CCI and MSS injuries and with moderate injuries is indicative of nonspecificity of the disorders found, since they are a typical pathologic process peculiar for traumatic injury of any genesis and localization. 3. The state of selenium metabolism does not possess correlations with other clinical and biochemical laboratory indices. 4. Selenium deficiency requires administration of pharmacological correction, for example, with Selenase which is essential both in acute and post-traumatic periods.
\end{abstract}

Citation: Vasiuk V. Le., Kovalchuk P. Ye., Tulyulyuk S. V., Shutka V. J. (2019) Selenium in Biological Fluids in the Bodies of Patients with Associated Trauma. World Science. 8(48), Vol.2. doi: 10.31435/rsglobal_ws/31082019/6631

Copyright: (C) 2019 Vasiuk V. Le., Kovalchuk P. Ye., Tulyulyuk S. V., Shutka V. J. This is an openaccess article distributed under the terms of the Creative Commons Attribution License (CC BY). The use, distribution or reproduction in other forums is permitted, provided the original author(s) or licensor are credited and that the original publication in this journal is cited, in accordance with accepted academic practice. No use, distribution or reproduction is permitted which does not comply with these terms.

The antioxidant system is of an extremely great importance in protection of the body against the effect of free radicals. Its main enzyme is glutathione peroxidase. This enzyme catalyzes decay of hydrogen peroxide $\left(\mathrm{H}_{2} \mathrm{O}_{2}\right)$ and lipid hydroperoxides, reduces hydrogen peroxide, hydroperoxide of 
corticosteroid hormones, cholesterol, linoleic and linolenic acids, intermediate products of prostaglandin biosynthesis, DNA peroxide etc., protecting cellular membranes against damage by the products of free radical oxidation (FRO).

Selenium is a cofactor of glutathione peroxidase. Nowadays selenium is known to possess strong antioxidant properties, participate in Krebs cycle reactions, pentose-phosphate cycle, and is one of the main components of the respiratory chain (3). Moreover, selenium activates protein synthesis, participate in antihistamine and anti-allergic mechanisms, normalizes metabolism of proteins and nucleic acids $(7,8)$.

Modern literature widely covers the role of selenium and necessity of its intake in case of different diseases, but the studies concerning the dynamics of concentration of this element in patients with injuries of the muscular-skeletal system (MSS) and cranial-cerebral injuries (CCI) are isolated. At the same time, investigation of selenium metabolism in case of injuries of the MSS and CCI and development of the correction schemes are generally known to enable to improve the results of treatment considerably and decrease the consequences of injuries.

Objective: to investigate the concentration of selenium in biological fluids in patients with associate trauma.

Materials and methods. 42 patients, treated at the Traumatological Department for adults and Neurosurgical Department of the Emergency Rescue Hospital in Chernivtsi, were examined. All the patients were distributed into 3 groups: I group - patients with severe CCI and injuries of the MSS requiring vital activity support; II group - with moderate CCI and injuries of the MSS; III (control group) - with injuries of MSS only.

I group included 12 patients with an average age of $40,8 \pm 0,5$ years. There were $33,3 \%$ of women and $66,7 \%$ of men. The main cause of the received injuries was a road accident -8 (75\%). Associated trauma was found in all the patients. The selection criterion to this group was severe CCI, assessment by Glasgow scale equal to $9-11$ points. The signs of hypovolemic shock were determined in 5 $(41,6 \%)$ patients on admission. In $6(50 \%)$ patients CCI was associated with fractures of legs, $5(41,6 \%)$ - femoral fractures, $1(8,3 \%)$ - fracture of the humeral bone. Fragments were fixed by means of the external fixation apparatus in all the patients. An average staying of patients at the intensive care units was $6 \pm 2,3$ days.

II group included 16 patients with an average age of $39,6 \pm 0,5$ years. There were $31,25 \%$ of women and $68,75 \%$ of men. The main case of the received injuries was a road accident $-11(68,75 \%)$. Associated trauma was found in all the patients. The selection criterion to this group was moderate CCI. The signs of hypovolemic shock were determined in 4 (25\%) patients on admission. In 10 $(62,5 \%)$ patients CCI was associated with fractures of leg, $5(41,6 \%)$ - femoral fractures, $1(8,3 \%)-$ fractures of the humeral bone. Fragments were fixed by means of the external fixation apparatus in all the patients. An average staying of patients at the intensive care units was $4 \pm 1,8$ days.

The control group included 14 patients with an average age of $43,6 \pm 0,5$ years. There were $35,7 \%$ of women and $64,3 \%$ of men. The main case of the received injuries was a road accident -8 $(57,1 \%)$. Associated trauma was found in all the patients. The selection criterion to this group was mild CCI. In $11(78,5 \%)$ patients CCI was associated with fractures of legs, in $5(21,5 \%)$ - femoral fractures. Fragments were fixed by means of the external fixation apparatus in all the patients.

While estimating selenium metabolism, its concentration in the blood plasma, erythrocytes and urine was examined. The material for examination was taken during an acute period of the disease $(1,7$ and 14 days). Blood in the volume of $5 \mathrm{ml}$ was taken from the vein by means of the cutaneous puncture followed by centrifugation. Before centrifugation officinal heparin solution in the dose of $250 \mathrm{UN} / \mathrm{ml}$ was added to the blood. Centrifugation was conducted with the use of the laboratory centrifuge SM6.03 at the speed of rotation of 1500 rotations per minute. 2 fractions were isolated in the result of centrifugation in the specimen: blood plasma and blood corpuscles - erythrocytes. $1 \mathrm{ml}$ was taken from the obtained fractions for examination. Both specimens were frozen at the temperature of $-33^{\circ} \mathrm{C}$.

Urine was taken in the morning in the volume of $1 \mathrm{ml}$. Then urine was frozen at the temperature of $-33^{\circ} \mathrm{C}$.

The specimens were examined using selective atomic-absorptive analyzer МГА-915.

The material was statistically processed with the use of the software Statisticav.5.5. Shapiro-Wilk normality test was used to check the distribution. The hypothesis concerning statistical similarity of the two samples was checked by means of Student criterion, correlation analysis - by means of Spearman criterion.

Results. Results of the examination of selenium concentration in the blood plasma, erythrocytes and urine of patients with CCI and injuries of the MSS are presented in the Table 1. 
The data obtained are indicative of decreased selenium concentration in all the biological media of the body (plasma, erythrocytes, urine) during the whole post-traumatic period, both in patients with severe CCI and injuries of the MSS and those with a moderate degree.

Table 1. Selenium concentration (in $\mathrm{mcg} / \mathrm{L}$ ) in plasma, erythrocytes and urine in patients with associated trauma

\begin{tabular}{|c|c|c|c|c|}
\hline \multirow[t]{2}{*}{ Characteristics } & \multirow{2}{*}{$\begin{array}{l}\text { Control group } \\
(\Pi=14)\end{array}$} & \multicolumn{3}{|c|}{$\begin{array}{l}\text { Patients with severe CCI and injuries of the MSS } \\
(\Pi=12)\end{array}$} \\
\hline & & 1 day & 7 day & 14 day \\
\hline Selenium in plasma & $85.56 \pm 3.2$ & $47.35 \pm 2.23$ & $59.34 \pm 2.56$ & $76.43 \pm 2.89$ \\
\hline $\begin{array}{l}\text { Selenium in } \\
\text { erythrocytes }\end{array}$ & $15.32 \pm 7.1$ & $82.72 \pm 3.22$ & $99.25 \pm 3.80$ & $104.31 \pm 4.57$ \\
\hline Selenium in urine & $10.01 \pm 2.5$ & $7.21 \pm 0.76$ & $8.56 \pm 1.12$ & $9.01 \pm 1.54$ \\
\hline \multirow[t]{2}{*}{ Characteristics } & $\begin{array}{l}\text { Control group } \\
(\Pi=14)\end{array}$ & \multicolumn{3}{|c|}{$\begin{array}{l}\text { Patients with moderate CCI and injuries of the MSS } \\
(\Pi=16)\end{array}$} \\
\hline & I day & 1 day & 7 day & 14 day \\
\hline Selenium in plasma & $85.56 \pm 3.2$ & $51.35 \pm 4.69$ & $62.54 \pm 5.67$ & $80.34 \pm 5.71$ \\
\hline Selenium in erythrocytes & $115.32 \pm 7.1$ & $99.43 \pm 8.45$ & $103.35 \pm 9.76$ & $105.65 \pm 9.93$ \\
\hline Selenium in urine & $10.01 \pm 2.5$ & $8.35 \pm 1.89$ & $9.21 \pm 1.78$ & $9.49 \pm 1.69$ \\
\hline
\end{tabular}

According to the results of the study the concentration of selenium in all the fluids during the whole post-traumatic period was reduced both in patients in coma conditions and in conscious patients. And considerable differences between the groups were not found, though the indicated changes were reliable in comparison with the parameters in the control group.

Considering the fact that a part of patients required ALV and specific therapy, we have conducted a comparative analysis of selenium concentration depending on the obtained injuries and applied therapy - a considerable difference in parameters was not found. It enabled us to conclude that decreased selenium concentration in the biological fluids is peculiar for any traumatic injury and is a pathogenic part of systemic inflammatory response syndrome.

Therefore, the lack of considerable differences in selenium concentration in patients with severe CCI and MSS injuries and with moderate injuries is indicative of non-specificity of the disorders found, since they are a typical pathologic process peculiar for traumatic injury of any genesis and localization.

On the basis of the data obtained the dynamics of selenium concentration can be suggested to be an autonomic process that does not depend on the level of non-specific therapy performed.

Conclusions. 1. Pronounced disorders of selenium metabolism are evidenced to occur in patients with severe CCI and MSS injuries, which are manifested by its decreased concentration in all the examined biological media of the body during the whole acute period of injury. 2. The lack of considerable differences in selenium concentration in patients with severe CCI and MSS injuries and with moderate injuries is indicative of non-specificity of the disorders found, since they are a typical pathologic process peculiar for traumatic injury of any genesis and localization. 3. The state of selenium metabolism does not possess correlations with other clinical and biochemical laboratory indices. 4. Selenium deficiency requires administration of pharmacological correction, for example, with Selenase which is essential both in acute and post-traumatic periods.

\section{REFERENCES}

1. Казиахмедов В.А. Динамика свободнорадикальных процессов при тяжелой черепно-мозговой травме / Ю.С. Александрович, И.Ю. Аруцова, С.Н. Львов, В.А. Казиахмедов // Сборник докладов и тезисов I I I съезда анестезиологов и реаниматологов Северо-Запада России. - СПб, 2005. - С.10-12.

2. Казиахмедов В.А. Содержание селена в биологических жидкостях при тяжелой черепно-мозговой травме / Ю.С. Александрович, В.А. Казиахмедов, В.В. Хорунжий, И.Ю. Аруцова, Г.М. Раевская // Сборник докладов и тезисов III съезда анестезиологов и реаниматологов Северо-Запада России. - СПб, 2005. - С.102 - 106.

3. Микроэлементозы человека: Этиология, классификация, органопатология / А.Н. Авцын, Л.Л. Жаворонков, М.А. Риш и др. - М., 1991. — 348 с.

4. Бабенко Г.А. Микроэлементозы человека: патогенез, профилактика, лечение / Г.А. Бабенко // Микроелементы в медицине. - 2001. - Т. 2 (1). - С. 2-5.

5. Zagrodzki P., Nicol F., Arthur, J.R. Slowiaczek M. Selenoproteins in human thyroid tissues // Biofactors. - 2001. - Vol. 14. - P. 223-227.

6. Holmgren A. Selenoproteins of the thioredoxin system // Selenium. Its Molecular Biology and Role in Human Health / Ed. by D. L. Hatfield. — Boston, 2001. — P. 189-205. 